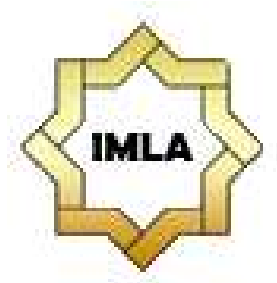

Al-Ta'rib

Jurnal Ilmiah Program Studi Pendidikan Bahasa Arab IAIN Palangka Raya

Vol. 9, No. 1, June 2021, 99-110

p-ISSN 2354-5887 | e-ISSN 2655-5867

https://doi.org/10.23971/altarib.v9i1.2603

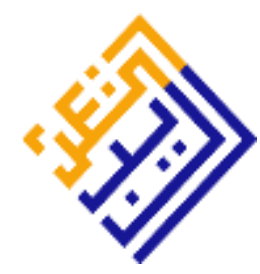

\title{
INNOVATION IN LEARNING ARABIC READING SKILLS USING HIGHER ORDER THINKING SKILLS
}

\author{
Aulia Mustika Ilmiani', Delima², \\ 1,2Institut Agama Islam Negeri Palangka Raya, Indonesia \\ E-mail: aulia.mustika.ilmiani@palangkaraya.ac.id
}

\begin{abstract}
This study aims to describe Arabic Reading Skills learning activities with the HOTS (Higher Order Thinking Skill) system. The research method used is a qualitative method based on text analysis. This study indicates that HOTS-based Arabic Reading Skills learning activities categorized into three levels: Level of Analysis, Level of Evaluation, and Level of Creation. First, the Level of Analysis is oriented towards the ability of students to distinguish the form of the word Isim or fi'il from a text, distinguish and classify the position of fi'il, fa'il, or maf'ul, describe the content text using a concept map, and link main ideas or compare information about a topic from reading results. The second is the level of evaluation which is oriented towards students' ability to check or determine errors in writing letters, vocabulary, language rules, and punctuation in a text, and criticize, refute, conclude, provide reviews or reasons, and communicate reading results with different expressions. Third, the level of creation is oriented towards the ability of students to formulate a statement sentence into a question, or vice versa, reconstruct a reading text into a conversation, and produce reading results by developing thoughts or opinions into ideas or notions.
\end{abstract} Keywords: Text Analysis; Higher Order Thinking Skills; Arabic Reading Skills

\section{Abstrak}

Penelitian ini bertujuan untuk menjabarkan kegiatan pembelajaran Maharah Qira'ah dengan sistem HOTS (Higher Order Thinking Skill). Metode penelitian yang dilakukan adalah metode kualitatif berdasarkan analisis teks. Hasil penelitian ini menunjukan bahwa kegiatan pembelajaran Maharah Qira'ah berbasis HOTS dikategorikan menjadi tiga level yakni level analisis, level evaluasi, dan level mencipta. Pertama, level analisis berorientasi pada kemampuan peserta didik untuk dapat (1) membedakan bentuk kata Isim atau fi'il dari sebuah teks, (2) membedakan dan mengklasifikasikan posisi fi'il, fa'il atau maf'ul, (3) menggambarkan isi teks dengan menggunakan peta konsep, dan (4) menghubungkan ide pokok atau membandingkan informasi mengenai sebuah topic dari hasil bacaan. Kedua, level evaluasi berorientasi pada kemampuan peserta didik untuk dapat (1) memeriksa atau menentukan kesalahan dalam penulisan huruf, penggunaan kosakata, kaidah bahasa dan tanda baca dalam sebuah teks, (2) mengkritisi, menyanggah, menyimpulkan, memberikan ulasan atau alasan dan mengkomunikasikan kembali hasil bacaan dengan ungkapan yang berbeda. Ketiga, level mencipta berorientasi 
kepada kemampuan peserta didik untuk dapat (1) merumuskan kalimat pernyataan menjadi sebuah pertanyaan atau sebaliknya, (2) merekonstruksi sebuah teks bacaan menjadi sebuah percakapan (3) memproduksi hasil bacaan dengan cara mengembangkan pemikiran, atau pendapat menjadi sebuah ide atau gagasan.

Kata Kunci: Analisis Teks; Higher Order Thinking Skills; Maharah Qira'ah

\section{Introduction}

Reading is a process carried out to obtain information and messages in the text (Musaffak \& Setiawan, 2020). Reading is an attempt to understand other people's thoughts and feelings through writing or pictures (Ilmiani, 2017). Its purpose is to express written language accurately and regularly. Through reading activities, a person can achieve higher cognitive abilities, such as explaining, creating ideas, evaluating, analyzing, and solving problems (Musaffak \& Setiawan, 2020). By reading, everyone can learn and interact with the outside world. In any language learning, reading skills are the components of language skills that get the most attention of language experts and researchers. Reading proficiency is a component of skills that involves memory, experience, brain, knowledge, language skills, psychological and emotional states (Zahra, 2011).

Reading skills play an essential role in any language learning class, including learning Arabic as a foreign language. Foreign language learners read text not only to understand unknown words but also the meaning of entire sentences. However, this is not the only purpose of reading the text. Language learners at a higher level expect to go beyond the sentence to get the meaning intended by the author because, in every part of the text, there must be hidden ideas and messages that cannot be overlooked (Rifda Haniefa, 2016). It is what is meant by critical reading.

Critical reading is a wisely, tolerantly, deeply, evaluatively, and analytically done reading. Furthermore, it is not only intended to look for mistakes (Manarin, 2019). Critical reading is the main asset for students to achieve success in learning (Watkins, 2020). Learners need critical reading skills to acquire and integrate knowledge, expand and deepen knowledge, analyze and evaluate knowledge, and apply critical reading skills in meaningful tasks. Maziyah (2018) states that generally, critical reading (interpretive reading or creative reading) requires readers to understand the author's intent. The readers also require assessing the author's arguments, apply critical principles to everyday reading, and increase reading interest, reading skills, and critical thinking. Knowing the principles of choosing reading materials and reading magazines or serious periodic publications is also required (Joseph et al., 2015; Parry, 2016).

Harmey (2021) believes that foreign language learning is more motivating when learners focus on something other than languages, such as problems, ideas, and opinions. Other than that, Moss (2021) also explains that learning a new language demands flexibility and higher-order thinking skills, and critical thinking can contribute to the academic success of learners. Therefore, nowadays, making learners more aware and responsible for their knowledge and thinking is highly emphasized (Afflerbach et al., 2015). Furthermore, there is a need to improve learners' ability to find information that is not stated directly in the text. Their learning is also the process of learning (Afflerbach et al., 2015). Rubinstein and

Jurnal Ilmiah Program Studi Pendidikan Bahasa Arab IAIN Palangka Raya Vol. 9, No. 1 /99-110 Al-Ta'rib | p-ISSN 2354-5887 | e-ISSN 2655-5867 
Firstenberg, Lochhead and Whimby, and Wood (1987) and Bezemer \& Cowan (2021) have proposed a solution to this problem. They recommend that critical thinking should be taught explicitly for the transfer of the entire academic domain. To understand the written text well, learners require more interaction with the text. In this interaction, Nist and Mealey (1991) in Musaffak \& Setiawan (2020) believe that metacognition in reading tasks is most influential. Wallace \& Wray (2013: 7) explains that critical reading ability rests on judging the extent to which the author provides adequate justification for the claims he makes (Yan \& Jaeger, 2020). Some judgments depend on what the author has communicated, and others depend on other relevant knowledge, experiences, and inferences brought into a frame of mind (Watkins, 2020).

In learning Arabic, reading has its urgency, which has a complex structure, levels, and understanding (Syahri, 2020). Learning is transferring knowledge by carrying out monotonous activities, where students are only the objects of listeners. Concerning language learning in higher education, reading does not only aim at obtaining information in the form of knowledge and experience, but it also aims to familiarize students with critical reading (Rahmawati, 2018). In line with that, reading proficiency in learning Arabic should be taught Higher Order Thinking Skills (HOTS).

According to Thomas and Thorne in Febriani et al. (2020), HOTS is a higher way of thinking than memorizing facts or applying rules, formulas and procedures. HOTS requires us to perform based on facts, make connections between facts, categorize them, manipulate them, place them in new contexts or ways, and apply them to find new solutions to a problem (Faruq \& Huda, 2020). The ability to think basic (lower-order thinking) only uses limited abilities on routine and mechanical matters (Carroll \& Harris, 2020), for example, memorizing and repeating the previously provided information. Meanwhile, HOTS stimulates students to interpret, analyze, or even manipulate previous information to be not monotonous (Ainin, 2018). HOTS is used by receiving new information and storing it for later use or rearranging it for problem-solving purposes based on situations (Febriani, 2020).

This HOTS requires students to use new knowledge and previous knowledge to process new information to get conclusions related to new situations (Harun, 2020). In languages, "high-order thinking is the ability to process information in its own way that is not memorizing facts or simply repeating information obtained previously" (Mulyaningsih \& Itaristanti, 2018). According to Muradi et al., HOTS is a mental process by maximizing the ability to think comprehensively to finds the desired goal (Muradi et al., 2020).

HOTS (Higher Order Thinking Skills) is a thinking skill that requires memory skills and other higher skills. Indicators to measure Higher Order Thinking Skills include analyzing skills (analyzing, C4), evaluating (evaluating, C5), and creating (creating, C6) (Hamidah, 2018); (Brookhart, 2010). Carroll \& Harris (2020); Madhuri et al. (2012) have explained that HOTS types build upon classroom learning objectives, which consist of three categories: 1) HOTS as transfer, 2) HOTS as critical thinking, and 3) HOTS as problem-solving. To narrow down the research analysis, we focus on HOTS-based Arabic Reading Skills learning activities. Only here is it interpreted as something that has not been 
taught before. HOTS as a transfer includes analyzing, evaluating, creating, creative thinking, logical thinking (Banich \& Compton, 2018) summarized into analyzing, evaluating, and creating.

In fact, in the field, implementing HOTS-based learning activities is complex for educators to implement in teaching and learning activities (Kamarudin et al., 2016). Therefore, many studies in the form of research analysis try to introduce, describe, and explore more deeply related to HOTS-based Arabic learning. Rahmawati's research (2018) regarding HOTS-based learning describes a variety of strategic activities carried out in learning Arabic so that students achieve highlevel thinking skills starting with HOTS indicators: (1) Level of Analysis, (2) Level of Evaluation, and (3) Level of Creation.

Furthermore, research was conducted with the object of learning Arabic in schools or madrasas. Hamidah (2018) says that in the context of the 2013 Curriculum, learning objectives can be matched with Basic Competencies. To design HOTS-based learning, teachers can analyze each Basic Competency in the curriculum and determine the GPA (Competency Achievement Indicator) regarding Basic Competency mapping. This is the first step in designing HOTSbased learning.

On the other hand, Ainin (2018) also discusses HOTS as a form of assessment to measure high-order thinking skills as indicated by critical, analytical, logical, creative, and metacognitive thinking. Functionally, the assessment is feedback to determine the success of learning, both in process and results. Even the assessment activity also serves to assess the assessment itself.

In several field studies, several schools have succeeded in implementing HOTS-based Arabic learning. Febriani (2020) states that learning Arabic at SDIT Al-Azhar Padang has met HOTS (Higher Order Thinking Skills) learning standards with an indication that learning Arabic requires student creativity and innovation to dig up information about vocabulary, sound, and sentence structure independently through the role of the teacher in integrating media, materials, and digital-based evaluation. On the contrary, in some HOTS-based Arabic learning research, efforts are still being made in stages, as Faruq \& Huda (2020) did in their research. The research results stated that Arabic teaching and learning activities at MAU Darul 'Ulum Step-2 of Ministry of Religion have already been using the 2013 Curriculum. However, educators cannot apply the HOTS method optimally (Palar, 2020).

Some of the research above still leads to the analysis of HOTS-based Arabic learning in general, such as learning Arabic in schools and madrasas. However, there has not been any research conducted that focuses on learning Arabic for one language ability. Therefore, this paper focuses on the analysis of Arabic Reading Skills learning based on HOTS learning. Arabic Reading Skills is considered one of the most dominant foreign languages used directly or indirectly at the basic, intermediate, or high levels.

This paper will formulate what activities in Arabic Reading Skills learning are under which level and what levels contained in the learning system (Higher Order Thinking). Using qualitative research and library research, the researcher will review the overall theory and research before describing the learning activities of Arabic Reading Skills with HOTS. 


\section{Method}

A qualitative approach with library research methods was used in this study. Qualitative research aims to understand what phenomena are experienced by research subjects holistically through descriptions in words, specific natural contexts, and various scientific methods. In connection with this study, reviewing various literature related to Arabic Reading Skills and Higher Order Thinking Skills (HOTS) was conducted in this research.

With a learning background of Arabic Reading Skills as a subject in the Arabic Language Education Study Program, the focus point of this research was the activities carried out in the Arabic Reading Skills learning process. This research was conducted based on the urgency side of curiosity about forming a HOTS-based Arabic Reading Skills learning system in various activities.

The research method schemes were as follows:

Approach: Qualitative

Method: Library Research

Data Collection Technique: Books, Article, Magazine

This research was a review of various literature that strengthened the analysis of the issues raised. Furthermore, the presented analysis results were supported by various sources with theoretical depth from experts on HOTS and Arabic language teaching. It was expected that this analysis would be helpful as a basis and reference in developing Arabic learning, primarily Arabic Reading Skills learning.

The research steps that the researchers carried out were: 1) determining the scope of a problem to be researched, namely Arabic Reading Skills Learning based on the HOTS learning system, 2) looking for information that was relevant to the problem, namely everything related to information about HOTS-based Arabic learning, 3) assessing several fundamental theories that were relevant to the problem, namely the theory of Arabic Reading Skills and HOTS-Based Learning, 4) looking for a theoretical basis as a guide for approaching problem solutions and thinking in order to formulate hypotheses tested in research, 5) deepening the researchers' knowledge about the problem and the field, and 6) reviewing the results of the previous related research.

\section{Result and Discussion}

From the previous research, Arabic Reading Skills learning activities based on Higher Order Thinking Skills (HOTS) are Level of Analysis, Level of Evaluation, and Level of Creation. The Level of Analysis consists of distinguishing, organizing, and connecting. 
Distinguish: the ability to distinguish is an integral part of everyday life. To achieve this ability, examples of Arabic Reading Skills activities in learning Arabic based on HOTS include distinguishing isim (noun) or fi'il (verb) in a reading or conversational text, distinguishing the categories of fi'il, fa'il, and maf'ul in a reading or conversational text, and comparing information about a topic from reading results.

Organize: with organizational skills, students can create schemes, charts, and various organizational charts. To achieve this ability, examples of Arabic Reading Skills activities in learning Arabic based on HOTS include classifying sentences containing main ideas and supporting ideas and describing the contents of the text/conversation using a mind map or concept map.

Connect: students must be able to analyze various information using various points of view. To achieve this ability, examples of Arabic Reading Skills activities in learning Arabic based on HOTS include creating keywords from a text and linking information in the field with discourse in reading text.

Previously, in research conducted by Rahmawati (2018), HOTS-based Arabic learning at this Level of Analysis included activities to distinguish word positions in fi'il, fa'il, and maf'ul bih. However, in the findings of this research, HOTS-based Arabic Reading Skills learning activities can be explored more by doing similar activities from the essential things, such as distinguishing isim and fi'il, and distinguishing harfu jar and harfu zhorof letters. After students master this ability, they must organize words, phrases, or clauses in a sentence, for example, making a concept map from a text or making a chart or a table so that the meaning of the content of the text is easier to understand.

In principle, the Level of Evaluation is the ability to make decisions based on criteria. This level consists of checking and criticizing skills. To achieve this ability, the students can follow the activities in learning Arabic based on HOTS below.

Check: checking is a process to find inconsistencies or errors in a process or product to achieve this capability. To achieve this ability, several activities are applied in learning Arabic based on Higher Order thinking Skills (HOTS) include checking or determining errors in writing letters, vocabulary usage, language rules, and punctuation in a text.

Criticize: In the Indonesian dictionary, criticism is defined as a response accompanied by descriptions and good and bad considerations of work, opinion, and the like. To achieve this ability, several activities are applied in learning Arabic based on Higher Order Thinking Skills (HOTS) include criticizing or refuting information obtained from the text read and providing statements, support, or rejection as a reaction to the information.

Kamarudin et al. (2016) add that at this level, teachers can assign students into groups by creating a discussion forum or creating a debate forum for students with a particular topic. There would be affirmative and proposition groups on the topic. The students then read a text containing arguments which state whether they agree or disagree on the topic. The findings of this research can be explored through pair discussion activities, group discussions, and structured discussions between teachers and students. 
Also, Muradi et al. (2020) argue that at this level, HOTS-based Arabic learning activities can be conducted by getting to know more about the specified figures and by carrying out reading activities in order to gain insight. The students can criticize the criteria of these figures in terms of expertise, fields, achievements, and life history.

The final level is Level of Creation. At this highest level, students organize various information using new or different ways or strategies than usual. Students are trained to combine parts to form something new, coherent, and original. As Polly \& Ausband (2009) state, the level of creation consists of formulating and producing.

Formulating: formulating is a form of creative thinking to explore various imaginations, ideas, or new points of view to overcome a problem. To achieve this ability, examples of learning Arabic Reading Skills activities include formulating a statement sentence into a question sentence and changing the reading text material (qiro'ah) to conversational material (hiwar), or vice versa.

Producing: producing or constructing is a follow-up to planning something to achieve this ability. Examples of Arabic Reading Skills applied in learning Arabic based on Higher Order Thinking Skills (HOTS) include creating a conversation or discourse from the predetermined main idea sentences and supporting ideas, developing a structured script with a predetermined theme, and demonstrate a conversational dialogue from a conversation text.

The findings in this study shows that Arabic Reading Skills learning activities are already at the highest level. The students are expected to think and be innovative through directed activities. Thus, even though it is an Arabic Reading Skills learning activity, the students can indirectly explore other language skills, such as the ability of Maharah Istima, Maharah Kalam, and Maharah Kitabah since there is a synergy that is interrelated with three other language skills. With structured and systematic activities, students can better recognize their abilities and desire to enrich their abilities by learning more exciting and challenging activities. In line with the principles of HOTS-based Arabic learning, through this system we can make assessments as they should.

An example of learning Arabic Reading Skills based on Higher Order Thinking Skill:

$$
\text { مهارة التفكير العالي في مهارة القراءة: }
$$



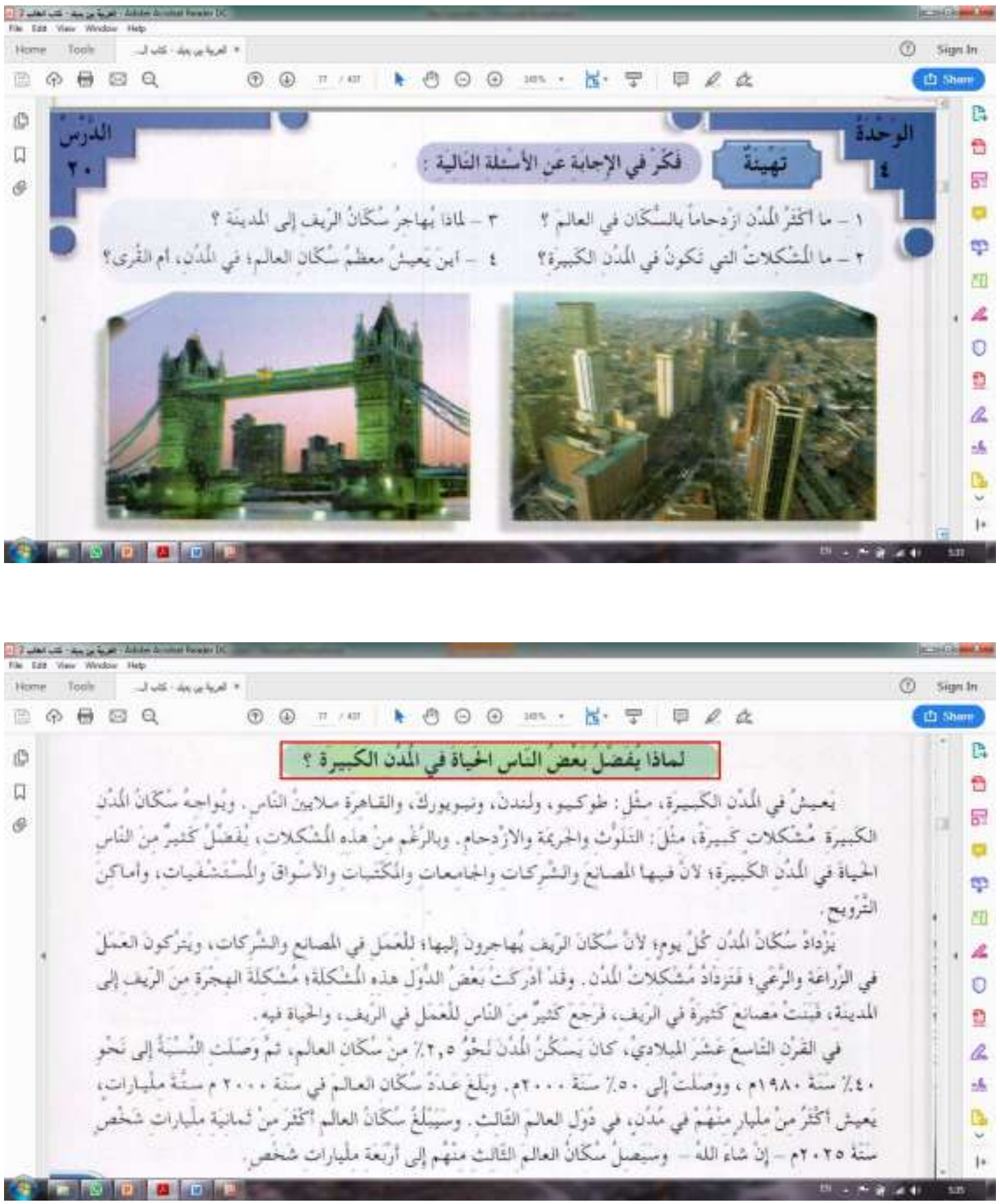

The first, Level of Analysis; . . . يعليش الناس في المدن الكبيرة لأن (النحيل)

At the analysis level, an example of a question related to the text above is " . . . . . . In this question, there is no direct answer in the text. However, students can analyze it with statements that support the context of the sentence. 


\section{The second, Level of Evaluation. . . التقويم) الحياة في الريف لها مشكلات كثيرة منها}

At the evaluation level, an example of a question related to the text above is ". . . الحياة في الريف لها مشكلات كثيرة منها ". To this statement, there is no direct answer in the text. However, students can evaluate it with statements that support the context of the sentence.

\section{The third, Level of Creation;. . . الإبداع) ايهما تفضل الحياة في الريف أم في المدينة)}

At the creation level, an example of a question related to the text above is “. . . ايهما تفضل الحياة في الريف أم في المدينة ". To this statement, there is no direct answer in the text. However, students can answer it by writing personal opinions related to experiences or empirical facts in the field.

\section{Conclusion}

From the results of the literature review that has been conducted, it can be concluded that some activities in learning Arabic Reading Skills that can be done to achieve HOTS are per the level and activity indicators. The conclusion is as follows. On the Level of Analysis, Arabic Reading Skills learning activities that can be done at this level are distinguishing isim (noun) or fi'il (verb) in a reading or conversational text, distinguishing the categories of fi'il, fa'il, and maf'ul in a reading or conversation text, comparing information about a topic from reading results, making a classification between sentences containing main ideas and sentences containing supporting ideas, describing the contents of the text/ conversation using a mind map or concept map, creating keywords from a text, and linking information in the field with discourse in the reading text. On the Level of Evaluation, Arabic Reading Skills learning activities that can be done at this level are checking or determining errors in writing letters, the use of vocabulary, the rules of the language, punctuation in a text, criticizing or refuting the information obtained from the text read and providing statements, support, or rejection as a reaction to the information. On the Level of Creation, Arabic Reading Skills learning activities that can be done at this level are formulating a statement sentence into a question sentence, changing reading text material (qiro'ah) to conversational material (hiwar) or vice versa, creating a conversation or discourse from the main idea sentences and the supporting ideas that have been determined, developing a structured script with a predetermined theme, and demonstrating a conversation dialogue from a conversation text.

According to the research results that have been done, we recommend further research related to language skills in terms of HOTS-based listening skills (Maharah Istima'), speaking skills (Maharah Kalam), and writing skills (Maharah Kitabah).

\section{Reference}

Afflerbach, P., Cho, B.-Y., \& Kim, J.-Y. (2015). Conceptualizing and Assessing HigherOrder Thinking in Reading. Theory into Practice, 54(3), 203-212. Https://Doi.Org/10.1080/00405841.2015.1044367 
Ainin, M. (2018). Penilaian Dalam Pembelajaran Bahasa Arab Di Madrasah Atau Sekolah: Hots, Mots Atau Lots? Prosiding Konferensi Nasional Bahasa Arab, $4(4), 155-165$.

Banich, M. T., \& Compton, R. J. (Eds.). (2018). Executive Function and Higher-Order Thinking. In Cognitive Neuroscience (4th Ed., Pp. 332-366). Cambridge University Press. Https://Doi.Org/10.1017/9781316664018.013

Bezemer, J., \& Cowan, K. (2021). Exploring Reading in Social Semiotics: Theory And Methods. $\quad$ Education 3-13, 49(1), 107-118. Https://Doi.Org/10.1080/03004279.2020.1824706

Carroll, K. A., \& Harris, C. M. (2020). Using A Repetitive Instructional Intervention to Improve Students' Higher-Order Thinking Skills. College Teaching, 0(0), 1-9. Https://Doi.Org/10.1080/87567555.2020.1823310

Faruq, U., \& Huda, M. M. (2020). Bahasa Arab Berbasis Peningkatan Pembelajaran Hots (Higher Order Thinking Skills) (Kajian Pembelajaran Bahasa Arab Di Madrasah Aliyah Unggulan Darul 'Ulum Step 2 Kemenag Ri). Al-Hikmah: Jurnal Kependidikan Dan Syariah, 8(1), 1-20.

Febriani, S. R. (2020). Analisis Implementasi Pembelajaran Bahasa Arab Di Sekolah Dasar: Hots, Mots, Lots? Prosiding Konferensi Nasional Bahasa Arab, 6(6), 432-444.

Febriani, S. R., Harun, U. B., \& Hasanah, H. (2020). Holographic Media for Vocabulary Learning-Based HOTS. Proceeding of International Conference on Engineering, Technology, And Social Sciences (Iconetos), 1(1), 10-13.

Harmey, S. (2021). Perspectives on Dealing with Reading Difficulties. Education 313, 49(1), 52-62. Https://Doi.Org/10.1080/03004279.2020.1824702

Harun, U. B. (2020). Project-Based Learning Integrated to Stem (Stem-Pjbl) To Enhance Arabic Learning Hots-Based. Al-Bidayah: Jurnal Pendidikan Dasar Islam, 12(1), 139-150. Https://Doi.Org/10.14421/Al-Bidayah.V12i1.230

Hasanatul Hamidah, M. A. (2018). Merancang Langkah-Langkah Stategis Pembelajaran Bahasa Arab Berorientasi Hots Untuk Menyongsong Era Industri 4.0. Multaqa Nasional Bahasa Arab, 1(1), 1-12.

Ilmiani, A. M. (2017). Ta'līm Mahārah Al-Qirā'ah Fī Dhou' Al-Nadzarīyah AlBināīyah Al-Ijtimā'īyah Li-Vigovsky: Dirāsah Hālah Fī Jāmi'ah Palangka Raya Al-Islāmīyah Al-Hukūmīyah. Al-Ta'rib: Jurnal Ilmiah Program Studi Pendidikan Bahasa Arab Iain Palangka Raya, 5(2), 117-126. Https://Doi.Org/10.23971/Altarib.V5i2.771

Joseph, H. S. S. L., Bremner, G., Liversedge, S. P., \& Nation, K. (2015). Working Memory, Reading Ability and The Effects of Distance and Typicality on Anaphor Resolution In Children. Journal of Cognitive Psychology, 27(5), 622-639. Https://Doi.Org/10.1080/20445911.2015.1005095

Kamarudin, M. Y., Yusoff, N. M. R. N., Yamat, H., \& Ghani, K. A. (2016). Inculcation of Higher Order Thinking Skills (Hots) In Arabic Language Teaching at 
Malaysian Primary Schools. Creative Education, 7(2), 307-314. Https://Doi.Org/10.4236/Ce.2016.72030

Madhuri, G. V., Kantamreddi, V. S. S. N., \& Goteti, L. N. S. P. (2012). Promoting Higher Order Thinking Skills Using Inquiry-Based Learning. European Journal of Engineering Education, 37(2), 117-123. Https://Doi.Org/10.1080/03043797.2012.661701

Manarin, K. (2019). Why Read? Higher Education Research \& Development, 38(1), 11-23. Https://Doi.Org/10.1080/07294360.2018.1527296

Maziyah, L. (2018). Membaca Kritis Teks Arab Argumentasi: Teori Dan Praktik. Prosiding Konferensi Nasional Bahasa Arab, 4(4), 73-81.

Moss, G. (2021). Literacies and Social Practice: Sociological Perspectives on Reading Research. Education 3-13, 49(1), 41-51. Https://Doi.Org/10.1080/03004279.2020.1824701

Mulyaningsih, I., \& Itaristanti, I. (2018). Pembelajaran Bermuatan Hots (Higher Order Thinking Skill) Di Jurusan Tadris Bahasa Indonesia. Indonesian Language Education and Literature, 4(1), 113-128. Https://Doi.Org/10.24235/Ileal.V4i1.2970

Muradi, A., Mubarak, F., Darmawaty, R., \& Hakim, A. R. (2020). Higher Order Thinking Skills Dalam Kompetensi Dasar Bahasa Arab. Arabi: Journal of Arabic Studies, 5(2), 177-190. Https://Doi.Org/10.24865/Ajas.V5i2.293

Musaffak, M., \& Setiawan, A. (2020). Membaca Kritis Sebagai Salah Satu Langkah Antisipasi Misinformasi Di Masa Pandemi. Prosiding Seminar Nasional Bahasa Dan Sastra Indonesia (Senasbasa), 4(1), Article 1. Http://ResearchReport.Umm.Ac.Id/Index.Php/Senasbasa/Article/View/3708

Palar, Y. N. (2020). Peningkatan Hots Dalam Pembelajaran Bahasa Indonesia Melalui Model Pembelajaran Berbasis Masalah (Problem Based Learning) Di Iakn Manado. The Way Jurnal Teologi Dan Kependidikan, 6(1), 1-17.

Parry, B. (2016). Reading Ads, Reading the World. Education 3-13, 44(3), 325-338. Https://Doi.Org/10.1080/03004279.2014.991413

Polly, D., \& Ausband, L. (2009). Developing Higher-Order Thinking Skills Through Webquests. Journal of Computing In Teacher Education, 26(1), 29-34. Https://Doi.Org/10.1080/10402454.2009.10784628

Rahmawati, N. (2018). Pembelajaran Bahasa Arab: Menuju Higher Order Thinking Skills (Hots). Prosiding Konferensi Nasional Bahasa Arab, 4(4), 149-154.

Rifda Haniefa, 2303412055. (2016). Efektivitas Pendekatan Metakognitif Dalam Meningkatkan Keterampilan Membaca Bahasa Arab Dan Berpikir Kritis Pada Siswa Kelas Xi Man Kendal [Other, Universitas Negeri Semarang]. Http://Lib.Unnes.Ac.Id/29423/

Syahri, Z. (2020). Pembelajaran Qiraah Dalam Bahasa Arab. Al-Kahfi: Jurnal Pendidikan Agama Islam, 5(1), 96-109. 
Watkins, V. (2020). Reading Collaborative Reading Partnerships in A School Community. Changing English, 27(1), 15-33. Https://Doi.Org/10.1080/1358684x.2019.1682966

Yan, S., \& Jaeger, T. F. (2020). Expectation Adaptation During Natural Reading. Language, Cognition and Neuroscience, 35(10), 1394-1422. Https://Doi.Org/10.1080/23273798.2020.1784447

Zahra, A. (2011). Pengembangan Program Hot Potatoes Sebagai Alat Evaluasi Kemahiran Membaca Dalam Pembelajaran Bahasa Arab Siswa Kelas Xi Bahasa Sma Negeri 4 Pasuruan. Skripsi Jurusan Sastra Arab - Fakultas Sastra Um, 0(0), Article 0. Http://Karya-Ilmiah.Um.Ac.Id/Index.Php/SastraArab/Article/View/13099

\section{Copyright Notice}

Authors retain copyright and grant the journal the right of first publication with the work simultaneously licensed under a Creative Commons Attribution 4.0 International License that allows others to share the work with an acknowledgement of the work's authorship and initial publication in this journal. 